\title{
PENGARUH MODEL PEMBELAJARAN KOOPERATIF TIPE TWO STAY TWO STRAY (TSTS) DENGAN PENDEKATAN BRAIN-BASED LEARNING TERHADAP HASIL BELAJAR KIMIA MATERI POKOK STRUKTUR ATOM DAN SISTEM PERIODIK UNSUR PADA SISWA KELAS X SMAN 1 KEDIRI
}

\author{
Rina Yulianti ${ }^{1}$, Muntari ${ }^{2}$, Mukhtar Haris ${ }^{2}$ \\ ${ }^{1}$ Alumni Program Studi Pendidikan Kimia FKIP Universitas Mataram \\ ${ }^{2}$ Program Studi Pendidikan Kimia FKIP Universitas Mataram \\ Email: rina.yulianti33@gmail.com
}

\begin{abstract}
Abstrak: Penelitian ini bertujuan untuk mengetahui pengaruh model pembelajaran kooperatif tipe Two Stay Two Stray (TSTS) dengan pendekatan brain-based learning terhadap hasil belajar kimia materi pokok struktur atom dan sistem periodik unsur pada siswa kelas X SMAN 1 Kediri. Penelitian ini merupakan quasi experimental, dengan bentuk nonequivalent control group design with proxy pretest. Sampel terdiri atas dua kelas yang diperoleh menggunakan teknik purposive sampling. Kelas $\mathrm{X}_{\mathrm{B}}$ sebagai kelas kontrol menggunakan metode konvensional (ceramah dan diskusi kelompok) dan kelas $\mathrm{X}_{\mathrm{C}}$ sebagai kelas eksperimen menggunakan model pembelajaran kooperatif tipe Two Stay Two Stray (TSTS) dengan pendekatan brain-based learning. Posttest yang digunakan untuk mengukur hasil belajar siswa berupa tes pilihan ganda. Berdasarkan hasil posttest pada kelas $\mathrm{X}_{\mathrm{B}}$ diperoleh nilai rata-rata 68 dengan ketuntasan klasikal 43,75\% sedangkan pada kelas $X_{C}$ nilai rata-rata adalah 54 dengan ketuntasan klasikal 15,78\%. Berdasarkan nilai rata-rata dan ketuntasan klasikalnya, model pembelajaran kooperatif tipe two stay two stray (TSTS) dengan pendekatan brain-based learning tidak memberikan pengaruh yang lebih baik daripada metode konvensional (ceramah dan diskusi) terhadap hasil belajar kimia materi pokok struktur atom dan sistem periodik unsur pada siswa kelas $\mathrm{X}$ SMAN 1 Kediri. Hal ini terjadi karena beberapa hal, yakni faktor internal dan fakor eksternal yang mempengaruhi hasil belajar, baik berupa keseriusan, minat dan perhatian, maupun penguasan siswa terhadap metode pembelajaran yang diterapkan.
\end{abstract}

Kata kunci : Two Stay Two Stray (TSTS), Brain-Based Learning, Hasil Belajar Kimia

\begin{abstract}
This study is a quasy experimental that purposing to know the effect of Two Stay Two Stray cooperative learning using brain-based learning approach towards the students' chemistry learning achievements on atomic structure and elements periodic system for $\mathrm{X}$ grade students of SMAN 1 Kediri. The learning result used are cognitive aspect. The instrument uses for data collecting are a multiple choice test. Based on the class XB posttest results obtained average value 68 with classical completeness $43.75 \%$ while the XC-class average value is 54 with a classical completeness $15.78 \%$. Based on the average value and classical completeness, cooperative learning model two stay two stray (TSTS) with brain-based learning approach does not give a better effect than the conventional method (lecture and discussion) on learning outcomes chemistry subject matter of atomic structure and systems periodic elements in class $\mathrm{X}$ of SMAN 1 Kediri. This happens for several reasons, namely internal factors and external factors that affect learning outcomes, either in the form of seriousness, interest and attention, as well as students' mastery learning methods applied.
\end{abstract}

Keywords: Two Stay Two Stray (TSTS), Brain-Based Learning, chemistry learning achievements.

\section{PENDAHULUAN}

Struktur atom dan sistem periodik unsur merupakan salah satu materi pokok awal pada pembelajaran kimia bagi siswa kelas X SMA. Oleh karena itu, dapat kita katakana bahwa kedua materi tersebut menjadi pintu gerbang bagi pemahaman siswa terhadap materi-materi kimia selanjutnya. Berdasarkan informasi (wawancara) yang diperoleh dari guru kimia SMAN 1 Kediri, siswa cenderung kesulitan memahami materi struktur atom dan sistem periodik unsur, sehingga berakibat pada rendahnya hasil belajar siswa pada materi pokok tersebut. Untuk meningkatkan hasil belajar, maka diperlukan pengetahuan terkait apa yang mempengaruhi hasil belajar siswa.

Menurut Slameto [1] terdapat beberapa faktor yang mempengaruhi hasil belajar siswa, diantaranya adalah metode mengajar, interaksi guru dengan siswa, dan interaksi siswa dengan siswa. Secara umum, guru kimia di SMAN 1 Kediri masih menggunakan metode konvensional dalam pengajarannya, metode konvensional yang lazim digunakan adalah ceramah dan diskusi kelompok. Kedua metode tersebut belum mampu menjawab tuntutan nilai ketuntasan minimal yang pada Tahun Pelajaran 2013/2014 akan meningkat dari 70 menjadi 75 .

Berdasarkan kebutuhan untuk menciptakan sebuah proses pengubahan sikap dan tata laku tersebut, maka pemerintah Indonesia, baik dalam Kurikulum Tingkat Satuan Pendidikan (KTSP) maupun dalam rancangan Kurikulum 2013, telah menetapkan karakteristik pendidikan yang harus dibangun adalah berpusat pada potensi, perkembangan, kebutuhan, dan kepentingan peserta didik dan lingkungannya [2]. Artinya, peserta didiklah yang menjadi titik pusat atau sentral dari sebuah proses pendidikan.

Telah banyak penelitian yang berusaha mengembangkan pembelajaran yang berpusat ke siswa. Salah satunya adalah pembelajaran dengan pendekatan brain-based learning atau pembelajaran berbasis otak. Pendidikan berbasis otak dimaknai sebagai keterlibatan strategi yang didasarkan pada prinsip-prinsip yang berasal dari suatu pemahaman tentang otak [3]. Dengan menggunakan apa yang kita ketahui tentang otak, kita dapat mengambil keputusan lebih baik dan menjangkau lebih banyak pembelajar [3]. Setelah mempertimbangkan kedua-belas prinsip dasar dan tiga 
unsur dalam brain-based learning tersebut, maka model-model pembelajaran kooperatif seperti experiential learning, problem-based learning, maupun cooperative learning dapat dinilai sebagai pembelajaran yang sesuai dengan otak selama dapat menghormati peserta didik sebagai individu yang unik dengan konteks sosio-kulturalnya masing-masing [4].

Pembelajaran kooperatif dengan kelima prinsip utamanya yang diimplementasikan melalui sintaks tipe two stay two stray dirasa akan dapat memperkuat interaksi positif antara siswa dengan siswa, sedangkan brain-based learning yang menunjukkan bagaimana guru sebagai fasilitator pembelajaran dapat secara peka melihat bagaimana kecenderungan otak siswanya bekerja dan menyediakan iklim belajar yang baik, dirasa akan mampu memperkuat interaksi positif antara guru dan siswa. Dengan demikian, diharapkan hasil belajar siswa akan menjadi lebih meningkat.

\section{METODE PENELITIAN}

Jenis penelitian ini adalah quasi experimental dengan bentuk desain nonequivalent control group design with proxy pretest. Populasi dalam penelitian ini adalah seluruh siswa kelas X SMAN 1 Kediri Tahun Pelajaran 2013/2014. Sampel dalam penelitian ini yaitu seluruh siswa kelas $\mathrm{X}_{\mathrm{B}}$ (kontrol) dan seluruh siswa kelas $\mathrm{X}_{\mathrm{C}}$ (eksperimen). Teknik sampling yang digunakan yaitu purposive sampling. Variabel yang diamati berupa variabel bebas (model pembelajaran kooperatif tipe Two Stay Two Stray dengan pendekatan Brain-Based Learninig) dan variabel terikat (hasil belajar kimia siswa). Hasil belajar dalam penelitian ini yakni hasil belajar kognitif siswa.

Teknik pengumpulan data dalam penelitian ini secara ringkas tergambar dalam Tabel 1. Data hasil proxy pretest dianalisis menggunakan teknik statistik, meliputi uji normalitas, uji homogenitas varians, dan uji Anova [5], sedangkan data posttest dianalisis secara deskriptif [6]. Data hasil observasi dianalisis baik secara kuantitatif maupun deskriptif. Lembar observasi dianalisis berdasarkan hasil skor yang diperoleh, kemudian ditentukan kriteria kerjasamanya. Penentuan kriteria kerjasama disusun berdasarkan petunjuk teknis penyusunan perangkat penilaian afektif SMA [7].

Tabel 1. Teknik Pengumpulan Data

\begin{tabular}{|l|l|l|l|}
\hline \multicolumn{1}{|c|}{ Variabel } & \multicolumn{1}{|c|}{ Data } & Sumber Data & \multicolumn{1}{c|}{ Cara Mendapatkan } \\
\hline 1. Kemampuan awal siswa & Skor & Siswa & Tes (Proxy pretest) \\
\hline 2. Hasil belajar siswa & Skor & Siswa & $\begin{array}{l}\text { Tes hasil belajar (multiple } \\
\text { choice posttest) }\end{array}$ \\
\hline $\begin{array}{l}\text { 3. Kelancaran penerapan } \\
\text { pembelajaran }\end{array}$ & $\begin{array}{l}\text { Skor dan catatan } \\
\text { keterangan }\end{array}$ & Observer & Lembar observasi \\
\hline
\end{tabular}

Tabel 2. Kriteria Kelancaran Proses Pembelajaran

\begin{tabular}{|c|c|}
\hline Rentang Persentase & Kriteria \\
\hline $20 \% \leq p \leq 36 \%$ & Sangat Kurang \\
$36 \% \leq p<52 \%$ & Kurang Baik \\
$52 \% \leq p<68 \%$ & Sedang \\
$68 \% \leq p<84 \%$ & Baik \\
$84 \% \leq p<100 \%$ & Sangat Baik \\
\hline
\end{tabular}

Tabel 3. Hasil Posttest Siswa

\begin{tabular}{|l|c|c|}
\hline & $\begin{array}{c}\mathbf{X}_{\mathbf{C}} \\
\text { (Eksperimen) }\end{array}$ & $\begin{array}{c}\mathbf{X}_{\mathbf{B}} \\
\text { (Kontrol) }\end{array}$ \\
\hline Jumlah Siswa & 19 & 16 \\
\hline Nilai Tertinggi & 85 & 90 \\
\hline Nilai Terendah & 40 & 50 \\
\hline Nilai Rata-rata & 54 & 68 \\
\hline $\begin{array}{l}\text { Ketuntasan } \\
\text { Klasikal }\end{array}$ & $15,78 \%$ & $43,75 \%$ \\
\hline Standar Deviasi & 13 & 12 \\
\hline
\end{tabular}

\section{HASIL PENELITIAN DAN PEMBAHASAN}

\section{Data Hasil Proxy Pretest}

Hasil analisis uji Anova diperoleh hasil bahwa tidak terdapat perbedaan hasil proxy pretest yang signifikan antara kelas $\mathrm{X}_{\mathrm{A}}, \mathrm{X}_{\mathrm{B}}, \mathrm{X}_{\mathrm{C}}$, dan $\mathrm{X}_{\mathrm{D}}$. Oleh karena itu dapat disimpulkan bahwa kemampuan awal untuk keempat kelas tersebut adalah sama atau homogen. Dengan demikian kedua sampel kelas $\mathrm{X}_{\mathrm{B}}$ dan $\mathrm{X}_{\mathrm{C}}$ memilik kemampuan proxy pretest yang sama. 


\section{Data Hasil Posttest}

Setelah melakukan posttest, diperoleh nilai rata-rata dan ketuntasan klasikal masing-masing kelas yang lebih lengkapnya tergambar pada Tabel 3.

Berdasarkan hasil analisis deskriptif nilai ratarata dan ketuntasan klasikalnya, dapat disimpulkan bahwa hipotesis penelitian ditolak. Hal ini berarti model pembelajaran kooperatif tipe two stay two stray (TSTS) dengan pendekatan brain-based learning tidak memberikan pengaruh yang lebih baik daripada metode telah ditentukan. Berdasarkan hasil catatan observasi aktivitas siswa, dapat terlihat bahwa beberapa siswa cenderung melakukan aktifitas pembelajaran sambil bermain-main bahkan hingga ada yang memukul-mukul meja. Slameto menyatakan bahwa faktor-faktor yang mempengaruhi belajar banyak jenisnya, tetapi dapat digolongkan menjadi dua golongan yaitu faktor intern dan faktor ekstern [1] . Keseriusan siwa dalam mengikuti pembelajaran merupakan salah satu faktor internal yang dapat mempengaruhi hasil belajar siswa [1].

Namun demikian, rendahnya hasil belajar pada kelas eksperimen juga dapat disebabkan oleh kurang optimalnya penerapan perencanaan pembelajaran oleh peneliti. Beberapa kendala yang dihadapi peneliti selama penerapan model pembelajaran kooperatif tipe TSTS dengan pendekatan brain-based learning ini, di antaranya adalah masih barunya proses pembelajaran dengan model dan pendekatan tersebut. Berdasarkan hasil observasi aktivitas siswa, terdapat $41 \%-59 \%$ siswa yang paham dan menjalankan tugasnya dalam bertamu maupun menerima tamu (Berdasarkan analisis hasil observasi poin $6,7,8$ ) dan pendekatan brain-based learning yang menuntut siswa untuk belajar berdasarkan pengalaman mereka sendiri (experiential learning) tentunya masih terasa asing bagi siswa yang terbiasa menerima penjelasan dari guru. Pengalaman semacam ini juga terjadi pada penelitian oleh Nola dkk [8] yang tidak mampu mencapai ketuntasan klasikal yang diinginkan dengan menggunakan model pembelajaran kooperatif tipe two stay two stray. Pada laporan penelitian Nola dkk dikatakan bahwa masih ada siswa yang tidak menjalankan tugasnya bertamu maupun menerima tamu, siswa cenderung hanya menyalin jawaban dari kelompok yang dikunjunginya.

Terlepas dari hal tersebut, pembelajaran dengan pendekatan brain-based learning mampu menarik perhatian siswa pada penyampaian motivasi dan tujuan pembelajaran. Pada pertemuan pertama, sekitar $60 \%$ 79\% siswa menunjukkan ketertarikan pada motivasi dan tujuan pembelajaran yang diberikan (Hasil analisis lembar observasi aktivitas siswa poin 1). Hal ini karena pengantar materi diberikan dengan menggunakan praktik sederhana menggunakan alat dan bahan yang dapat ditemukan sehari-hari dengan dipandu lembar kerja siswa (LKS) yang menarik.

Nilai rata-rata posttest kelas kontrol lebih tinggi dibandingkan nilai rata-rata posttest kelas eksperimen (Tabel 4.1). Penulis berpendapat bahwa tingginya nilai rata-rata posttest di kelas kontrol dapat dikarenakan konvensional (ceramah dan diskusi) terhadap hasil belajar kimia materi pokok struktur atom dan sistem periodik unsur pada siswa kelas X SMAN 1 Kediri.

Ada beberapa faktor yang peneliti anggap menjadi penyebab rendahnya capaian hasil belajar siswa kelas eksperimen. Selain dari segi strategi dan metode pembelajaran yang digunakan, hasil belajar siswa juga dipengaruhi oleh cara siswa belajar untuk mencapai indikator yang

oleh angka drop-out yang cukup tinggi di kelas tersebut. Dari 21 orang siswa yang mengikuti pretest, hanya 17 orang siswa saja yang mengikuti posttest (hanya 16 yang masuk perhitungan, sebab satu orang diantaranya tidak memiliki nilai pretest). Lima orang dari jumlah yang 21 tersebut tidak mengikuti posttest sedangkan terdapat satu orang yang tidak mengikuti pretest namun mengikuti posttest. Dari kelima orang yang tidak mengikuti posttest tersebut, hanya Ahmad Paezal dan Muhammad Hidayat yang menunjukkan nilai di atas rata-rata, sedangkan tiga orang lainnya menjadi penyumbang nilai rendah. Dengan hilangnya tiga orang penyumbang nilai rendah tersebut, maka tentunya berpengaruh positif pada pergeseran nilai ratarata posttestnya (Lampiran 28). Sedangkan pada kelas eksperimen, dari 22 orang siswa yang mengikuti pretest, terdapat 21 orang siswa yang mengikuti posttest. Terdapat tiga orang yang mengikuti pretest namun tidak pada posttest, sedangkan dua orang yang mengikuti posttest namun tidak pada pretest (kedua orang yang tidak memiliki nilai pretest ini tidak dimasukkan dalam analisis hasil belajar). Nilai pretest siswa yang tidak mengikuti posttest cukup rendah. Namun demikian, dengan hilangnya hanya dua orang yang memiliki nilai rendah tersebut dari analisis hasil belajar, penulis beranggapan bahwa sumbangan yang diberikan pada pergeseran nilai rata-rata posttest tidak terlalu signifikan.

\section{Data Hasil Observasi Kerjasama}

Lembar observasi yang telah diisin oleh observer dianalisis, baik secara kuantitatif maupun kualitatif. Secara singkat, persentase kelancaran proses pembelajaran berdasarkan aktivitas guru dan siswa tergambar pada Tabel 4 dan Tabel 5.

Tabel 4. Persentase Kelancaran Proses Pembelajaran berdasarkan Aktivitas Guru

\begin{tabular}{|c|c|c|}
\hline Pertemuan ke- & Persentase & Kategori \\
\hline 1 & $75 \%$ & Baik \\
\hline 2 & $66,67 \%$ & Baik \\
\hline 3 & $75 \%$ & Baik \\
\hline
\end{tabular}

Tabel 5 Persentase Kelancaran Proses Pembelajaran berdasarkan Aktivitas Siswa

\begin{tabular}{|c|c|c|}
\hline Pertemuan ke- & Persentase & Kategori \\
\hline 1 & $65,45 \%$ & Baik \\
\hline 2 & $61,81 \%$ & Sedang \\
\hline 3 & $67,27 \%$ & Baik \\
\hline
\end{tabular}


Dari segi perhatian, kelas eksperimen menunjukkan perhatian yang sangat rendah selama proses pembelajaran berlangsung. Hal ini tergambar dari hasil observasi aktivitas siswa pada pertemuan kedua yang menunjukkan angka cukup jauh, yakni $61,81 \%$ dibandingkan pada pertemuan pertama yang menunjukkan angka $65,45 \%$ dan pertemuan ketiga $67,27 \%$. Ketidak-seriusan tersebut juga tergambar dari catatan observer yang mengatakan, "Dari awal guru masuk kelas, hampir semua siswa terlihat tidak siap untuk menerima pelajaran kimia. Tidak ada satupun siswa yang membawa LKS yang sudah dibagikan pada pertemuan sebelumnya."

\section{KESIMPULAN DAN SARAN}

\section{Kesimpulan}

Berdasarkan analisis data dalam penelitian ini, dapat disimpulkan bahwa model pembelajaran kooperatif tipe two stay two stray (TSTS) dengan pendekatan brain-based learning tidak memberikan pengaruh yang lebih baik daripada metode konvensional (ceramah dan diskusi) terhadap hasil belajar kimia materi pokok struktur atom dan sistem periodik unsur pada siswa kelas X SMAN 1 Kediri. Hal ini terjadi karena beberapa hal, yakni faktor internal dan fakor eksternal yang mempengaruhi hasil belajar, baik berupa keseriusan, minat dan perhatian, maupun penguasan siswa terhadap metode pembelajaran yang diterapkan.

\section{Saran}

Berdasarkan penelitian yang sudah dilakukan, peneliti mengajukan beberapa saran yaitu:

1. Agar hasil belajar lebih maksimal perlu dilakukan usaha lain dengan memperhatikan faktor-faktor yang berpengaruh terhadap prestasi belajar siswa, seperti kesiapan siswa, perhatian, dan minat siswa terhadap pelajaran kimia, serta penguasaan siswa terhadap metode pembelajaran yang diterapkan.

2. Perlu dikaji penerapan model pembelajaran lain pada materi pokok struktur atom dan sistem periodik unsur.

\section{DAFTAR PUSTAKA}

[1] Slameto. 2010. Belajar dan Faktor-Faktor yang Mempengaruhinya. Rineka Cipta, Jakarta.

[2] Kementerian Pendidikan dan Kebudayaan. 2012. Dokumen Kurikulum 2013. Jakarta: Kementerian Pendidikan dan Kebudayaan.

[3] Jensen, Eric. 2011. Pemelajaran Berbasis-Otak: Paradigma Pengajaran Baru. Jakarta: PT Indeks.

[4] Gulpinar, Mehmet A. 2005. The Principles of Brain-Based Learning and Constructivist Models in Education. Educational Science: Theory \& Practice Vol. 5, No. 2: 299-306.

[5] Sugiyono. 2012. Metode Penelitian Pendidikan (Pendekatan Kuantitatif, Kualitatif, dan $R$ \& $D)$. Bandung: Alfabeta.

[6] Campbell DT, dan Cook TD. 1979.QuasiExperimentation Design \&Analysis Issues for Fields Settings. Chicago: Rand McNally College Publishing Company.

[7] Direktorat Pembinaan SMA. 2010. Juknis Penyusunan Perangkat Penilaian Afektif di SMA. Jakarta: Direktorat Pendidikan SMA.

[8] Nola, DG, Rery RU dan Erviyenni. 2012. Penerapan Pembelajaran Kooperatif Teknik Two Stay Two Stray (TSTS) untuk Mencapai Ketuntasan Belajar Siswa pada Pembelajaran Kimia di Kelas X-6 SMAN 12 Pekanbaru. Skripsi S1. Universitas Riau. 